\section{Shopping Center Industry Internationalization with a Focus on Key Resources and Direct Investment: The Case of a Chilean Company in Mexico}

\section{Humberto Riquelme}

Regional Leader of Payments and Vendor Processes at Parque Arauco, Cerro Colorado 5240, Torre del Parque 1, Piso 15, Las Condes, Santiago de Chile humberto.erm@gmail.com

\section{Vito Bobek}

University of Maribor, Faculty of Economics and Business, Slovenia and University of Applied Sciences FH Joanneum, Graz, Austria

vito.bobek@um.si,vito.bobek@fh-joanneum.at

\section{Tatjana Horvat}

University of Primorska, Faculty of Management, Koper, Slovenia

tatjana.horvat@fm-kp.si

\begin{abstract}
The shopping center sector has been growing steadily over the last years in Latin America. Many countries such as Chile, Mexico, and Brazil lead the industry in the region, with so many projects still under development and different companies with international expansion perspectives in their portfolio. The purpose of this paper is to identify which are the most recommendable entry mode strategies for Latin American countries and which are the essential resources and capabilities that a shopping center company needs to develop to increase the likelihood of success in the sector. Thus, different factors, such as political, economic, and social factors, which impact the industry operation, are analyzed to create a high-level overview of this industry's most important subjects. For this purpose, primary and secondary data are used, based on a literature review and an empirical qualitative study, giving information of the Chilean Commercial Real Estate company, and interviewing its top managers. Thereby, the results lead to an entry strategy proposal into the Mexican market, identifying the most important shopping centers in the country, the main actors, and the best opportunities to enter.
\end{abstract}

Keywords: shopping center sector, resources and capabilities, entry strategies, emerging markets, Chile, Mexico
ORIGINAL SCIENTIFIC PAPER

RECEIVED: OCTOBER 2020

REVISED: JANUARY 2020

ACCEPTED: FEBRUARY 2021

DOI: $10.2478 /$ ngoe-2021-0005

UDK: $330.322(83)(720)$

JEL: M16, F14

Citation: Riquelme, H., Bobek, V., \& Horvat, T. (2021). Shopping Center Industry Internationalization with a Focus on Key Resources and Direct Investment: The Case of a Chilean Company in Mexico. Naše gospodarstvo/Our Economy, 67(1), 46-60. DOI: 10.2478/ ngoe-2021-0005

\section{NG OE}

NAŠE GOSPODARSTVO OUR ECONOMY

Vol. 67 No.1 2021

pp. $46-60$ 


\section{Introduction}

Emerging economies have been the focus of international investors in recent years. One of the most exciting sectors in emerging markets is the shopping center industry. A shopping center is a specially built area containing one or several buildings, usually of considerable size, that houses services, shops, and commercial offices gathered in a given space that concentrates potentially more clients. The method of ownership varies from individual owners to multiple ones. The business model is based on the rental of the commercial spaces, where the tenant must pay for the rental and maintenance services to the shopping center (Shopping Center Business, 2020).

The shopping centers in Latin America have grown 5\% annually between 2008 and 2018 (Lizan, 2018). Mexico tops the list of countries with a significant number of shopping centers, followed by Brazil. The spread of these businesses follows the increase of foreign direct investment to Latin American countries, the rise of GDP per capita, and the increase of income in the middle class.

Most shopping center industry related data focuses on the United States, Europe, or Asia (mainly China and India). Little of the data is focused on Latin American countries, where the growth opportunities are still worth further examination (ECLAC 2011, 8).

It is difficult for foreign investors to choose an emerging market that meets the necessary conditions to make investments without risks. Most emerging countries display conditions of corruption, political uncertainty, bureaucracy, and social instability that are difficult (but not impossible) to face (Shumetie \& Watabaji 2019, 8).

This research questions of this paper are:

1. Which are the key resources and capabilities to increase the shopping center sector's success rate in Latin America?

- Assumption 1: Regional partnerships and policies

- Assumption 2: Experienced managers and teams

- Assumption 3: Innovation oriented policies

2. Which are the most recommendable entry strategies in the shopping center sector for Latin American countries?

- Assumption 1: Using a local partner

- Assumption 2: Using a direct entry investment

Consequently, this paper aims to understand and describe the key resources and capabilities that a shopping center company needs to develop to increase the likelihood of success in business ventures in emerging economies in Latin America. Another objective is to understand the most recommendable strategies for entering Latin American economies in the shopping center sector. The authors want to show relevant information for foreign investors looking for investment opportunities in emerging markets, and, for managers who are reluctant to expand abroad and/or find insights into their internationalization process. In addition to a critical reflection of important influences, this research gives an overview of different motivations and approaches of shopping center chains entering the Mexican market and insight into the Mexican business environment. Based on the experiences of a Chilean company, the paper provides recommendations for possible foreign market entries. A strategy is developed by analyzing the Chilean company $X$ 's previous experience entering other Latin American countries such as Perú and Colombia. The paper concludes with the required resources for international expansion and a proposal of an entry strategy into Mexico, according to an analysis of its economic, political, and social factors.

The paper begins with the literature review to deliver a precise observation of resources and capabilities, entry mode strategies, the shopping center industry, the analyzed company, and the Chilean business environment. Then, empirical research follows with a qualitative research approach which has been selected due to its ability to provide a deep insight into research. The empirical analysis is followed by a discussion where the analysis outcomes are dealt with. The conclusion summarizes the findings and explains the limitations of the study.

\section{Methodology and Data}

To answer the research questions, a qualitative approach was applied using primary research data. This qualitative approach was executed through interviews with experts (i.e., relevant managers in company $\mathrm{X}$ (10 persons)). Those interviews were conducted in a face-to-face conversation or, if not possible, via an online interview. These conversations were recorded to present the results and be analyzed according to the Mayring (2015) method. There were also secondary research data taking place to support more information about the research. The collection of information was executed through books, specialized magazines, private organizations, and government entities and associations.

The qualitative research approach was selected due to its ability to provide deep insight into the area of research. Moreover, this type of investigation involves verbalizing data for observing and interpreting them individually. This makes the process flexible and open for interpretation. Instead of a quantitative presentation of numbers, qualitative studies seek to articulate data by observing and interpret- 
ing it on an individual basis (Ebster \& Stalzer, 2008, pp. 139-140). To analyze the conducted expert interviews, the qualitative content analysis of Mayring (2015) has been identified as the appropriate tool.

\section{Literature Review}

The quantity of theory and research regarding the Latin American shopping center industry is very scarce. This is because most of the studies are made focusing on developed market areas, such as the United States, Europe, and China. In this framework, the study is based on understanding the main topics of the Latin American shopping centers contexts. These contexts include resources and capabilities, shopping center industry, the analyzed company, and Economic and Shopping Center context of Mexico.

\section{Resources and capabilities}

The business strategy perspective tells us that resources and capabilities are the sources of a company's internal strengths and weaknesses. Exploiting that the firms' unique $\mathrm{R} \& \mathrm{C}$ is a strong basis for profitability, growth, value creation, and other aspects that may determine a competitive success (Tallman, 2010).

Other authors (Dakare et al. 2019; Ferreira \& Fernandes 2017; López-Cabarcos et al. 2015) define 'resources and capabilities' as a basis for achieving competitive advantage and superior performance. Resources are the assets that organizations have or can call upon, while capabilities are how those assets are used or deployed. A shorthand way of thinking of this is that resources are "what we have", and capabilities are "what we do well" (Johnson et al., 2016, pp. 98-107). In this research, the authors have analyzed the following resources: physical, financial, and human resources.

Since one of the primary purposes of having essential resources and capabilities is to achieve a competitive advantage, it is possible to define this as a differential characteristic of a company that makes it stand out from the competition and place itself in a superior position compared to the rest, to obtain higher performance. The competitive advantage must be unique in its sector, appreciated by the consumer or end customer, and capable of being maintained over time. The companies can use any of the three generic competitive strategies (Cepyme News, 2020).

The concept of generic strategies is based on the fact that competitive advantage is the essence of any strategy, and that a decision is essential to achieve it. Thus, if the com- pany wants to achieve a competitive advantage, it must choose the type it wants to obtain and the area in which it will do so. "Making everyone happy" is considered a symbol of strategic weakness and below-market performance, as" making everyone happy" quite often means that there is absolutely no competitive advantage. The generic strategies below will be detailed (Porter, 2015): cost leadership, differentiation, focus, concentration, or specialization.

Gottschalk (2005, 50-52) states that standard strategic management models traditionally develop the firm's strategy according to its product and market positioning (the products they manufacture and the markets they work in). However, there is another critical approach to consider the resource-based strategy. This approach states that a company should position itself based on its unique, valuable, and inimitable resources and capabilities rather than its products and services. Leveraging R\&C across many markets and products, rather than targeting certain specific products for certain markets, becomes the strategic driver. Therefore, the resource-based strategy provides a longer-term insight than the traditional ones, and one more robust in uncertain and dynamic competitive environments.

The strategic resources and capabilities that make a company successful have to be unique or rare for seeking a competitive advantage and value creation. Like everything in a business environment, $\mathrm{R} \& \mathrm{C}$ does not last forever. They do not have a permanent condition (resources decay, capabilities decline, competitors will adapt to the market and find new sources of potentially more advantage). Thus, it is a clear and relevant activity to exploit the resources and capabilities the company already owns and controls. Not all complex capabilities are necessarily easy to understand or pin down, but the firms could still understand how their specific skills work. Resources and capabilities are only valuable if they can allow the company to create, make, or do something that allows them to create value for the customers (Tallman, 2010).

\section{Entry mode strategies}

Selecting an entry strategy will depend on various factors, such as the promise and size of the market, the business environment, managerial understanding of the market, internationalization objectives, fitting among product and market, the level of asset commitment for targeting a market, and finally the nature/level of competition (Cavusgil et al., 2012, 3-25, 84-104).

Having a strategy means that the company also has clarity about its objectives or wants to go to a particular market or country. Firms typically seek one of the following ob- 
jectives while investing abroad: 1 . Market seeking, where a firm is attracted to a market due to its size and potential; 2. Efficiency seeking, in which a firm wants to enter a new market due that the market has exceptional capabilities in a particular industry; 3. Resource seeking, in which a firm invests in a country to obtain access to a crucial resource (Buckley \& Ghauri, 1999, 361-381).

A Multinational Enterprise (MNE) looking to enter a foreign market has to make relevant strategic decisions regarding which entry mode strategy to use. The Entry Modes are specific forms of entering a new country to accomplish planned goals underlying international presence (Luo, 2002, 198-208).

The selection of potential markets to enter depends on external factors, since it is essential to consider internal ones and the company's cultural orientation. This orientation has a significant influence on a company's international operations, such as recruitment and deployment of employees, managers, and strategy formulation (Gekonge, 2013, 167-170).

\section{Shopping center industry}

In the last decade, the economy's globalization process has substantially impacted the internal territorial reorganization of metropolises that are shaping a "transnational urban system." One of the consequences of this process is the redefinition of urban centers around consumption, particularly to cultural consumption, leisure activities, and luxury trade, in response to the emerging demand from concentrated social sectors. The internationalization and modernization of commerce involve the diffusion of identical products and brands and the arising of a business sector of standardized places such as shopping centers. In Latin America, the shopping centers have been perceived as an urban symbol of the city's changes (Caprón, 1997).

According to the Spanish Association of Shopping Centers, shopping centers are defined as a set of independent commercial establishments, planned, and developed by one or more entities, with unity criteria. Their size, commercial mix, shared services, and complementary activities are related to their environment, which permanently has a unified image and management (Asociación Española de Centros Comerciales, 2020).

As we know it today, the shopping center was initially conceived by the architect Victor Gruen, which was determined by the European covered and pedestrian passages. Victor Gruen wanted to materialize a space that fulfilled a sociability function similar to that of urban centers with shopping streets. In the beginning, the shopping malls were designed as a space for consumption and recreation, a place for social life where the public could walk and relax (Lipovestdky, 2014).

The profitability and business model of shopping centers is achieved by renting the gross leasable area at the highest possible price. In addition to the income derived from the rental of commercial premises, the owners of shopping centers obtain additional income through the rental of common areas and the rental of billboards that are usually located outside the building where the shopping mall is located. The rental of common areas can be an essential source of income due to the stands seen in the corridors. The shopping center owners charge rent for the square meters they leisure for installing the children's attraction, the ice cream stand, watch or jewelry stores, to give some examples. Therefore, the method to procure income can be classified as (RB, 2017): business premises leases, rental of common areas, and billboards rental.

For having a prominent, prosperous, and strong shopping center business, there are different factors and parameters to keep in mind, all of which can involve the following (Dirigentes Digital Magazine, 2020): location, access, commercial mix, anchor stores, and facilities.

Some authors (Martin Gonzalez, 2009) also indicate the influence relevant to the shopping center's architecture on the consumer, summoning the "Gruen Effect" concept. Victor Gruen knew the influence that architecture had on psychology since one of his hobbies was to study the secrets of the symbolism of the great cathedrals.

\section{Company $\mathbf{X}$}

Company $\mathrm{X}$ is a public limited company based in Chile. It quotes its shares in the Chilean stock market, forming part of the Selective Price Index of Shares, S\&P IPSA. It measures variations of prices of the 30 most liquid companies on the Santiago Stock Exchange and on the General Stock Price Index, S\&P IGPA, which measures the performance of the shares domiciled in Chile and listed on the Santiago Stock Exchange and that have a stock market presence equal to or greater than $25 \%$ and which, also, meet other minimum liquidity criteria (Company X, 2019).

Company $\mathrm{X}$ develops and manages multi-format real estate assets, mainly for commercial use, oriented towards different socio-economic sectors in Chile, Peru, and Colombia. The company considered four shopping center types: regional, neighborhood, outlet malls, and strip malls. The 
tenants (clients) are department stores, home improvement stores, supermarkets, restaurants, cinemas, health centers, and smaller stores of different items (Company X, 2020). They study the cities of the countries where they are present and search for the best locations in each city. Once the location is chosen, they create tailored business concepts: the right size, the right infrastructure, and the optimal busi- ness mix. Finally, when the mall is built and leased to tenants (clients), they seek to continually improve the shopping experience for final consumers (visitors).

Currently, the company is involved in Chile, Perú, and Colombia, working with the following assets and characteristics (Company X, 2019):

Table 1. Assets of company X in Chile, Peru, and Colombia

\begin{tabular}{l|c|c|c}
\hline & CHILE & PERÚ & COLOMBIA \\
\hline $\begin{array}{l}\text { Real estate assets } \\
\text { (number of shopping centers) }\end{array}$ & 30 & 20 & 4 \\
\hline Total leasable area & $515.000 \mathrm{~m}^{2}$ & $405.500 \mathrm{~m}^{2}$ & $155.000 \mathrm{~m}^{2}$ \\
\hline Owned leasable area & $398.240 \mathrm{~m}^{2}$ & $405.500 \mathrm{~m}^{2}$ & $136.550 \mathrm{~m}^{2}$ \\
\hline Average leased occupation & $96.1 \%$ & $95.6 \%$ & $92.5 \%$ \\
\hline Average age of portfolio* & 17 years & Nine years & Six years \\
\hline Clients (tenants) & 1.559 & 1.508 & 677 \\
\hline Collaborators & 315 & 147 & 74 \\
\hline
\end{tabular}

Source: adapted from company X Memoria Annual (2019).

Note: *average age of all shopping centers owned by company $X$ in the country.

\section{Economic Context of Mexico}

Summarizing Mexico's economic, social, and political context, it is possible to establish that the country is well-positioned in every index among Latin American countries and is always located among the top four (WEF for the years 2015 to 2019). The country also possesses a strong economy, with a GDP that in the next 20-30 (years) is forecasting to be within the top ten economies worldwide Mexico has a current population of 120 million, which will increase around $25 \%$ by 2050, and with a high human capital development compared to Latin American countries (KNOEMA 2019). Mexico is an attractive market for global investors, with a capital market full of opportunities to develop.

Mexico also has the second-best infrastructure level in Latin American countries after Chile, with a level of urbanization among the highest globally, and Mexico City among the most populous cities worldwide. Nevertheless, the country is involved in an institutional context surrounded by high political corruption (ECLAC, 2016).

\section{Shopping Center Context of Mexico}

Since the 1990s, Mexico has registered an unprecedented boom in (the capture of) real estate investments, including those in commercial megaprojects. The first shopping malls that emerged in Mexico resulted from the association between department stores and national real estate developers (International Council of Shopping Centers (ICSC), 2015).

Alliances between department stores and domestic real estate developers facilitated Plaza Universidad's construction in 1969. It was the first shopping center in the country, resulting from a collaboration between the North American company Sears Roebuck and the real estate firm Sordo Madaleno. A similar operation laid the foundation for the building of Plaza Satélite in 1971, a product of the association of Sears Roebuck department stores, the Port of Liverpool, Paris, and London, also with with Sordo Madaleno (Gasca-Zamora, 2017, 75-84).

These complementarity schemes between commercial and real estate capital have been maintained over time in Mexico. Examples include the construction of the Perisur Shopping Center, Galerías Insurgentes, and Galerías Coapa, in which the El Puerto de Liverpool department store participated. For its part, El Palacio de Hierro participated in the Coyoacán Shopping Center (Gasca-Zamora, 2017, 75-84).

The growth of the Shopping Center sector is part of a new financial regime in the direction of contemporary urban production in Mexico and other Latin American countries, a system characterized by the participation, coalition, and merger of investors, real estate companies, and global and 
national financial actors, as well as for the diversity of funds and investment instruments managed by companies, including pensions, insurance and hedge funds (De Mattos, 2007).

The decade 2006-2016 witnessed an extraordinary transformation in the way real estate developments are viewed. Now, this industry in Mexico is in maturity, characterized by a boom in infrastructure development and growing national and foreign capital investment. It should be noted that the integration of real estate investment portfolios is a common practice today. Three trends that adequately describe the market are (KPMG, 2016):

1. The emergence of medium and small developers in strategic regions of the country;

2. The increase in mixed-use developments;

3. The rise of financial investment instruments, such as Real Estate Investment Trusts (better known as Fibras) and Development Capital Certificates (CKD).

The trend towards attracting high rents generated by shopping centers has triggered greater participation and competition from global investors for placement in different cities in Mexico, where significant capital flows are required in this segment of shopping centers and others related to the real estate market. Concerning the size of participating global companies, it is estimated that approximately 12 billion dollars was placed in various real estate sectors between 1999 and 2010. It should be noted that $80 \%$ of these investments came from the United States and Canada, while the rest of funds came from countries in Asia and the Middle East (Asociación Mexicana de Capital Privado, 2014).

According to UNCTAD's 2020 World Investment Report (UNCTAD, 2020), FDI inflows edged down to USD 33 billion, from USD 35 billion a year earlier (-5\%). The total stock of FDI was estimated at USD 628 billion in 2019. Investments mostly come from the United States, Spain, Canada, and Germany. The sectors receiving significant foreign investment were manufacturing (especially the automobile industry), financial and insurance services, retail and wholesale trade, and communication. Foreign investment is mostly concentrated in towns neighboring the US border (where many assembly factories are located) and the capital city. Thanks to its robust tourism industry, the Yucatan Peninsula also receives substantial foreign investment. FDI flows to the country fluctuate enormously depending on the arrival and departure of large international groups.

The different modalities of financing the real estate sector in the construction of shopping centers are channeled through different sources. Since the end of the nineties of the twentieth century and the beginning of the twenty-first, schemes have been identified that include Real Estate Investment Consortiums, mortgage providers, insurers, and various types of private equity funds. These include Kimco, Prei, General Electric Capital, ING, Hines, Black Creek, O'Connor and LaSalle Investment Management, MetLife, and Walton Street. In addition to the participation of these global companies, in more recent years, the financing of the Shopping Centers in Mexico has had a greater dynamism due to the emergence of various modalities of stock market investment, such as Development Capital Certificates (CKD) and Investment Trusts in Real Estate (FIBRAS). Both have contributed new resources to expand the margin for local capital participation from investors of different sizes (Lizan, 2014). In all sectors, Mexican commercial and development banks are taking more active roles in project finance deals, where financing is in pesos, fully funded by Mexican lenders and governed by Mexican law. The banks are more often seen as developers, seeking to decrease the exchange rate and internationally driven risks and to lower transaction costs (Lexology, 2020).

Mexico is a leader in developing shopping centers in Latin America, ahead of countries such as Brazil, Argentina, Colombia, Peru, and Chile. A condition that implies an opportunity for economic development, being a benchmark in the region since out of the 1,800 shopping centers that exist throughout Latin America, 584 are in this country (Forbes, 2015).

For the International Council of Shopping Centers (ICSC), with groups of more than 60,000 members in 80 countries, this trend experienced by the Mexican market is relevant. While Colombia and Peru's potential are experiencing expansion today, Mexico and Brazil are Latin American countries with the most developed shopping center industry and the largest potential for expansion (International Council of Shopping Center, 2020).

In Mexico, the shopping center industry began in the mid-sixties. At the end of the same decade, Mexico and Brazil had a mature sector, with investment opportunities in conurbations and new economic development poles in Brazil's case. Cities such as Monterrey, Guadalajara, Puebla, and the Federal District are already fully saturated with shopping centers. However, other areas in small municipalities and secondary cities still do not offer and present opportunities to develop shopping centers (Olguín, 2019).

Extensive international and national investment companies are generally associated with groups of Mexican and foreign developers, although some of these also participate as lessees, as holders of shares with investment and commercial companies, or participating in their divisions of financial companies. Therefore, it is possible to find different types of developers within shopping centers' construction and operation. 


\section{Empirical Analysis}

Comprehending the shopping center industry in general terms and its business model will allow us to develop this study's focus in a robust manner. Without knowing how Shopping center industry works, it is impossible to develop an exemplary structure of analysis and conclusions. However, to summarize the matter in a few points, the business model of shopping centers consists of developing, building, and operating shopping malls, creating different income strategies that commonly come from business premises leases, rental of common areas, billboard rental, and their main clients the store tenants.

The authors chose the qualitative approach. Its primary advantage is that it offers a complete description and analysis of a research subject without limiting the research scope and the nature of participants' responses (Collis \& Hussey, 2014, 5-6). Qualitative analysis is based on qualitative data such as text data from interview transcripts. This analysis is very dependent on the researcher's ability, integrative skills, and personal knowledge of the social context where the data is collected. A creative and investigative mindset is needed for qualitative analysis, based on an ethically enlightened and participant-in-context attitude and a set of analytic strategies (Miles \& Huberman, 1984, 10-13).

This qualitative approach will be applied through personal interviews to identify a participant's emotions, feelings, and opinions regarding a particular research subject. Personal interviews' main advantage is that they involve personal and direct contact between interviewers and interviewees and eliminate non-response rates (Fisher, 2017, 43-46). The goal of the interviews is to find personal opinions of wise and expert people on a particular topic, in this case, regarding the Shopping Center industry in Latin America.

To attain this goal of finding opinions, the interviews with the experts took place according to the required resources and capabilities to compete in the shopping center sector and the recommended entry strategies to enter other countries in Latin America. The interviewees consisted of a group of ten managers in Company $\mathrm{X}$.

The interviewees selected in Company X were only with (i) managerial positions with a minimum of 3 years of experience in the shopping center industry and (ii) professional background in other companies. Therefore, the authors consider them to have sufficient knowledge and experience in the shopping center industry.

These conversations were recorded and analyzed according to the Mayring (2015) method. Open-ended questions were defined as free-form survey questions that allow a respondent to answer in open text or voice format. They can answer based on their complete knowledge, feeling, and understanding. This means that responses to these questions are not limited to a set of given options (Bhat, 2020). Unlike a closed-ended question that leaves survey responses limited and narrow to the given options, an open-ended question allows researchers to probe deep into the respondent's answers, providing valuable information about the subject at hand. These questions' responses can then be used to attain detailed and descriptive information on a subject (Bhat, 2020).

The interview guide was divided into categories with 12 different questions to accomplish the goals of this research. Those categories are:

- C1: External factors (economic, social, and political).

- C2: Cultural differences.

- C3: Company X’s expansion status.

- C4: Company X's expansion opportunities.

- C5: Differences in shopping center industries.

- C6: Recommended entry methods.

- C7: Raising capital.

- C8: Company X’s differentiation (resources).

- C9: Other real estate differentiation (resources).

- C10: Company X's differentiation (capabilities).

- C11: Other real estate differentiation (capabilities).

- C12: Threshold resources \& capabilities.

The interviews were conducted in June 2020, all via video conference using Google "hangouts meeting" due to the COVID-19 pandemic. The time for each interview was from 40 minutes to 1 hour. Data was collected using the interview guide recording every video conference digitally on a tablet device to transcribe all conversation details afterward and attain the correct findings.

The interviews were scheduled for approximately one to two weeks to notify the interviewees about the main topic ahead of time. The interviews were held in Spanish, considering all interviewees were Spanish speakers from Chile, Perú, or Colombia. At the beginning of each interview, the partners were informed about the recording, and the questions were asked immediately prior to recording acceptance.

\section{Results}

The interview analysis was divided into four steps, according to Mayring (2015, 70-72):

1. Paraphrasing: At this point, all nonessential transcriptions were taken out. The text was transformed into a language which was easier to comprehend. Text components that added nothing to the content was omitted.

2. Generalization: These reductions allowed researchers to access phrases summed up to conclude one idea or statement. Related meanings could be applied, and synonyms could be eliminated. 
3. Reduction 1: A relationship between the previous generalizations was made, forming a new statement.

4. Reduction 2: In the second stage of reduction, several paraphrases referring to one another and occurring passage throughout the material were summarized and expressed in a single new statement.

As the content analysis of interviews required 16 pages of text, the results are explained in a condensed manner in the Discussion section.

\section{Discussion}

\section{Shopping center's resources}

Shopping center resources were addressed by categories 8 \& 9 in the interview guide.

Shopping center (SC) companies, like any enterprise in any market, must seek advantages and differentiating factors that could increase profitability and longevity. Those differentiators have to work as success factors for them. In this study, we wanted to understand the most critical resources and capabilities for shopping center companies, which would be essential to differentiate from the competition and increase the possibilities of succeeding in Latin American countries.

In the case of resources, we can find the following:

- Shopping center assets: iconic assets are one of the essential values of SC companies. Having this group of resources enables us to negotiate in a better way with investors, tenants, suppliers, and others. This is the essential leverage of the real estate world. Mainly, the infrastructure and the contracts housed within the iconic assets are a critical value the company holds when deciding to sell. A future investor (buyer) will be the building's tangible and intangible value with the potential future income it would generate. It is also relevant for public appearance, promotion, and visibility in the market.

- Human capital: the most important asset is always the employees. Every person is unique, each with different qualities and attributes. The way people work can be vastly different. Besides the employees, the executives and directors are relevant, as they are the ones who have to make the right decisions and create a high-level human group.

- Reputation: the reputation of the company is an intangible resource that is hard to create and maintain over time. Shopping center companies can negotiate better terms with investors and financial institutions (such as interest rates), when having a high reputation. That is a fundamental issue in real estate - being competitive and considering that there are long-term periods of income returns. Industry reputation can be attained by demonstrating consistency and good operative and financial behavior, which may lead to easy negotiations with partners, investors, and banks.

- High cash flow: this resource is relevant for the industry since it allows the industry to not be $100 \%$ dependent on external entities for seizing opportunities, considering that these opportunities are not available all the time. High cash flow also enables industry to be strong in the case of any unexpected contingency and pay any pending issue passively. Also, SC companies represent an adequate risk rate level, which is useful for receiving competitive interest rates in issuing bonds or receiving credit.

- Portfolio of funds: it is a relevant point that companies can maintain several contact options of funds. Following that line of thinking, SC companies would be capable of appealing to different entities for financing their projects.

- Landbank portfolios: this means that SC companies maintain lands as assets still unexploited. This is a common practice used in this industry, where companies buy terrain with a possible high valuation in the future according to their analysis and expectations. When terrains are at a low price, having land proficiency would be an excellent strategy to construct shopping centers years later, when the neighborhood's urbanization has been increased, and the price of the land is higher than before. This strategy provides high savings and a competitive advantage.

- Vertical integration: some shopping center companies in Latin America are also retailers, who are tenants at the same time (and many times anchor). This vertical integration is an advantage for shopping centers when they want to create new projects since they can build a new shopping center with their stores, guaranteeing a complete project from the beginning with less interaction and negotiations with other clients.

- Location: in commercial real estate, it is said that location is everything. To maximize the possibility of succeeding and to attract top tenants (clients), a good location is of significant value. Good location may consist of strong visibility from main roads, proximity to high public flow (demographics), good public transport connectivity (metro stations and public buses), and easy access to the shopping center itself (cars and pedestrians).

- Infrastructure and design: good infrastructure in shopping centers may be an essential issue in differentiation. Nowadays, the strategy of differentiation has been followed by many companies adapting concepts to innovative designs. Companies are also concerned about nature and global warming, using alternative energies, applying saving resources mechanisms, using structures with green areas, and high technology climatizationall with the primary goal of granting an excellent customer experience. 


\section{Shopping center's capabilities}

Shopping center capabilities were addressed by categories $10 \& 11$ in the interview guide.

Regarding capabilities, the following can be identified:

- Human capacities: this is well related to the human resources the company has, where distinguished experiences, knowledge, and skills may improve the company's success.

- Coordination of activities: In the shopping center industry, there are many activities to develop, not just creating a building with a good location and maintaining it. It is more than that; it is about creating a mall where the customer feels comfortable and wants to go. This is possible only by managing good structure coordination of different topics. Such topic includes facility management, cleaning, security services, entertainment, climatization, customer service, and parking. An excellent coordination capacity will differentiate a top shopping center from a common one.

- Commercial mix: this is the tenant mix that is subject to the layout of the shopping centers. It is important to have a high capacity to offer a mix of brands and concepts that attract consumers to buy products and services in tenants' stores. This importance lies in the fact that it is layout that will provide customers with an experience that will keep them coming back. The commercial mix will depend on the sort of tenants and their quality (is not the same for shopping center companies with big names such as H\&M, Zara, Polo Ralph Lauren, Dolce \& Gabbana, Gucci, or Luis Vuitton, then others SCs with unknown brands). That is why it is a crucial element to have strong capacities to create a high-profile tenants mix.

- Raising financial funds: this ability is fundamental for the sustainability of commercial real estate companies' expansion. The capability of raising funds means raising funds and negotiating business terms with other entities to receive money from different sources to accomplish its goals.

- Technology innovation capacities: the industry has been evolving in recent years. Technology is a relevant point to consider when data entry must be analyzed. Many software systems may assist companies in making better decisions in different terms. These include such actions as understanding customers' behavior, security systems accurately, management of efficiencies, parking services, customer services, maintenance efficiencies, energy reductions, and others. Every aspect is willing to offer an excellent service. Hence, SC companies must be aware of main industry innovations to differentiate themselves.

- Customization: this capability in the shopping center industry means companies' ability to understand the environment's needs (neighborhood) and their customers to create buildings that attract these customers. This factor demonstrates the adaptation capability of companies and social reading.

- Organizational culture: the organizational culture is an asset that involves many aspects. But in the shopping center, the industry makes a difference if a company can create a great environment that enables the employees to work with high standards, comfort, and happiness. It is the ability to recruit, motivate, potentiate, and retain talent. It is vital ability since a well-made culture can attract quality talent. Some examples of this are companies well-positioned in a great place to work index.

- Ability to transfer best practices: transferring the best practices among a group of countries. Finding the method of measure better and uniformly (verb) the activities to make them comparable, to manage, and find the best efficiencies in the shopping center company. Sometimes, international enterprises operate in each country in their own way, and that capacity of integration creates a differentiation.

In company X's case, the company has attained strategic differentiation by mainly working on significant development of shopping center buildings, human capital (with recruiting and retention programs) and Reputation in the market, high cash flow, and a strong portfolio of funds, and landbank portfolios. Furthermore, in capabilities, the company has been developing human capacities (knowledge and skills with educational and talent programs), commercial mix, activities coordination, and raising monetary funds.

Analyzing the minimum resources, a company must attain to survive in the shopping center industry consist of large retailer long term contract, high quantity of money, low-interest rates for financing, and attractive projects to receive a well welcome from the market costumers. Furthermore, capabilities need to do an excellent facility management (maintenance, climate, parking, elevators, etc.), Business knowledge (legal norms, retailers' knowledge, tenant contracts, operational execution, etc.) good Marketing strategy.

\section{Shopping center's market entry strategy}

Shopping Center market entry strategy was addressed by category 6 in the interview guide.

The research revealed that flexibility in finding the optimal formula to enter a new country in the shopping center industry is crucial. This flexibility is relevant to adapt to conditions and close deals with any local company disposed to sell a stake. The chosen option will depend on each situation, according to each market and each country.

At any rate, different strategies were shown in the interviews as the most recommended entry method to a new country: 
- Mergers and acquisitions (M\&A): M\&A are transactions where a certain ownership level of a Shopping Center company is transferred or consolidated with other entities, in this case, with an international company. This alternative uses the local country's firm assets and combines them with the investor's resources and capabilities (or buyer). M\&A allows us to receive local network access (to suppliers, tenants, and consumers), SC business knowledge, and relevant assets. This method also enables us to start a "Brownfield Project," which is the restructuring and renovation, or expansion, of an SC building. However, these costs may go beyond starting from zero as well as more time. It makes sense to buy existing assets since it will allow us to create a partnership with a local shopping center entity that knows in detail the country, who knows the rules, which gives specific stability at the beginning. It enables creating a base from where to expand further in the country after the first entry step is made (for example, starting with a shopping center in the capital city of a country and later expanding to other cities where opportunities are found). M\&A can be made only if an SC seller counterpart is found in the local market to enter. Therefore, sometimes strong efforts to negotiate conditions may be made. These conditions my include establishing the SC company brand name locally, attaining the possibility of operating the shopping centers, besides others. Nevertheless, this method facilitates a speedy entry to a new country, which is one advantage.

- Greenfield: for entering with this method, it is relevant to keep in mind that a suitable location must be reached. Obtaining fair land in a strategic position is critical. Sometimes, the landowners are unwilling to sell the terrain, and it is necessary to perform more negotiations with them. In some cases, a good form of agreement would be to create a long-term contract to rent the lands, and then build a shopping center on it or concede the land with a contract that splits the RSC's revenues between the parts. That is why it is vital to maintain a landbank in the countries where the SC company desires to enter, keeping the lands and waiting until the neighborhood's urbanization is such that the moment to build the mall is appropriate. With greenfield, a good project is necessary in addition to the lands. An advantage of this method is that it provides the chance to build from the beginning and according to the most suitable neighborhoods and environment context. Thus, the project can agree with the concept and model the Shopping Center company wishes. Greenfield's disadvantage is that it may take several months or years to analyze, determine the project, and negotiate with the local entities for entering the country. The negotiations may last long, especially with local institutions, such as the country government and municipalities. Sometimes, the local mayors (on where the shopping center is expected to be built) is high and can add bureaucracy to obtain the permits to operate and construct the building. It is also relevant to know the industry's development level and the ownership model established in shopping centers at the local level.

- Joint venture: a joint venture is also an alternative when selecting a method of entering a new country. In this case, a commercial agreement is made between 2 or more entities: denominated "Venturers" or partners. It is a transitory agreement where the parts are involved in a specific business with defined terms and tasks, creating synergies of knowledge, capabilities, resources, and/or assets of shopping centers. Some common alternatives of the SC industry to board this method are combinations of properties to create powerful mixed assets. Also, a JV between a partner who contributes with strategic leasing and management direction and the other part who lease and operate the assets. Besides, Joint ventures where one part is owning a significant part of a shopping mall and the other part provides property management and assets management. This method allows us to share efforts, risks, and responsibilities when the chances of succeeding by oneself are not high. A good advantage of JV is that it enables us to enter a new country in the SC industry with a local partner in less time than a greenfield, creating synergies and receiving funds through it. Some disadvantages may include a conflict of interest and discrepancies when establishing priorities and strategies between the partners.

According to the analysis, all previous strategies may work if the multinational Shopping Center company's operational control is attained, and a partnership with a local entity can be arranged. Otherwise, the possibilities to succeed in entering a new country will not be high, especially considering the risks involved (local industry knowledge, cultural issues, social behavior, besides others).

\section{Shopping center's financing}

Shopping center financing was addressed by the category 7 in the interview guide.

An entry method strategy is possible only if a good capital engagement strategy is determined. In the case of the shopping center industry, the are several recommended ways to attain these resources to accomplish the expansion goals:

- Bonds' issuance: shopping center companies can use this method to collect funds through the issuance of debt. The bonds are sold in the market where several investors can get the chance to buy these instruments. Hence, the investors can benefit from the price raising of those bonds in the future or the interest yields. Bond issuance is commonly used to finance investment projects as well as expansion.

- Minority share sales: this method is also a good alternative and very interesting to analyze. Shopping cen- 
ter companies sell their societies' participation or some assets to receive funds. This may be considered a type of "money recycling" since the company sells assets they obtained previously at a low price, adding value by operating the malls better, and then sells the assets at a higher price than before. Thus, the company also receives benefits from the starting acquisition.

- Private investors: this alternative is widespread in every market and industry. Private investment is the purchase of capital assets expected to grow in the future and then produce benefits. In the SC industry, this option can be used in every expansion project to receive funds. Here, the company seeks to sell the project's participation to a local entity in the country of expansion.

- Bank credits: this option is also widespread in every industry. The company goes to bank institutions to receive funds throughout a loan with an interest rate expected to pay during the lending period. This point is a crucial issue to have adequate finance background and behavior since low-interest rates are relevant to be competitive in the shopping center industry, considering the time of the loans, which are adequate to project periods in the long term.

- Own capital: capital is raised from the company's own resources. Using this method, the enterprise can use existing savings kept in a bank account, receive extra capital from the company owners, or sell other capital investments the company possesses to receive a cash flow to use for expansion.

- Stock market openings: this alternative can be applied just for companies that do not work on stock markets. Hence, entering the stock market can be a valuable method to raise income from investors by selling the company's stake through shares.

In the case of company $\mathrm{X}$, the company has been growing abroad using mostly Mergers \& Acquisitions and Greenfield projects. M\&A is the primary choice, entering new markets obtaining $51 \%$ of the participation or more, enabling them to take control of the operations and decisions of the shopping centers. Nevertheless, the entry strategy in each country was according to the general context them. In Colombia's case, the possibilities of entering with an M\&A strategy were complicated, considering the ownership model located there. One of the tenants was the landlords of the spaces, hindering the possibility of negotiating a purchasing of a Shopping Center since the only way to achieve it was bargaining with each of the landlords, representing an exhausting and even impossible task to accomplish. For Perú was different, and M\&A was applied because the industry conditions were like Chile, and it was appropriate to do it.

Company $\mathrm{X}$ is still only in South America, considering that there are still opportunities in the currently located countries since there is a combination of closeness and stability in current countries, more affinities, and similarities. One of the essential points is that Chilean retailers, such as Falabella and Cencosud, have entered those countries, enabling them to enter new markets with well-known Chilean retailers' anchor stores. Entering a new country demands strong efforts, and many factors are involved, such as the level of remoteness to operate and control (object).

Nonetheless, company $\mathrm{X}$ is still deciding if expanding to other new countries or continuing to grow in current countries, mainly diversifying to other real estate businesses, such as home properties, hotels, offices, among others. Despite this, there is a desire to grow to other new countries, and many opportunities and risks are involved. However, it is important to enter with critical assets and relevant positions. In opportunities, we see more countries in Latin America with cultural similarities, markets with low square meters per inhabitant with the potential to grow faster, more countries with economic stability, and low capital costs to expand. Furthermore, regarding risks, we observe that there would be difficulties in convincing foreign investors about expansion. The retailers to negotiate are not the same. There is a high probability of entering with market prominence, hidden expanding costs, the level of distances and time differences, the risks associated with expanding from zero, losing attained economies of scale, and the adaptation period long.

Also, differences between countries in the shopping center industry must be considered with malls' ownership model. In some countries, there are multi-owner (tenants are the owners of spaces and use them or rent them), and the single owner (a company manages the mall and rent spaces to different tenants). Moreover, investing ways, business rules, the type of infrastructure (which may be according to the urbanization, social or environmental conditions (as climate)), industry standards; operation models; and KPI's measurements are also vital.

\section{Selecting the target market}

Selecting the market was addressed by categories 1, 2, 3, 4, and 5 in the interview guide.

The decision to select a country to enter is a crucial task. Therefore, a collection of trustworthy information must be made. The first point to understand is choosing Mexico, and many elements come to mind when selecting the main issues. First, Mexico is one of the emerging markets with the best forecast in economic terms, considering it is expected the country to grow almost three times its GDP by 2050, positioning itself among the top 10 countries worldwide. The population is also forecasted to increase $20 \%$ by 2050 , from 126 million to 150 million (KNOEMA 2019). The country has a very developed middle class, with high-income levels and acquisition power (Euromonitor, 2020). 
The country's level of openness is at a high level, which means international trade is significant to the economy. Foreign investments are also part of it, with a well-developed capital market for the Latin American region, especially in the real estate industry, with the Real estate investment trusts (FIBRAS) and Development capital certificates (WEF, 2020).

The shopping center industry in Mexico surpassed the forecasts of 2014, predicting that in 2025 the industry would attain 23 million square meters of sales area. However, as recently as in 2020, the country reached that number, and the projections are still looking forward to growth (ADI, 2020).

Another relevant topic to mention is that some Chilean retailers such as Falabella are also expanding to Mexico, which allows easy access to negotiations for Company $\mathrm{X}$ to enter the country. There is also a common language and socio-cultural proximities with Chile. Both are Latin American countries, with acceptable life quality standards (mostly in great cities such as Monterrey, Guadalajara, and Mexico City), a high Shopping Center industry development, considering the second oldest in Latin America, after Brazil.

Nevertheless, there are factors to be aware of, which include the level of corruption in Mexico, political management (country, regional, and municipalities), bureaucracy, level of competition, and security, which the company will have to deal with and find strategies to diminish.

Thus, according to the study analysis, a good entry method strategy to Mexico for company X would be an M \& A, whose advantages were detailed previously. It is fundamental to enter the Mexican market with market reputation prominence, looking for top-ranked shopping centers to buy a stake.

There are two Mexican actors who own the top-tiers malls in Mexico: Fibra Danhos and Gicsa. Fibra Danhos owns "Parque Linda Vista”, "Parque Delta”, and "Parque Duraznos". In the case of Gicsa, they own "Paseo Arcos Bosques", "Forum Buenavista”, and "Paseo Interlomas”.

Furthermore, by analyzing the Net operational incomes (NOI) per square meter's efficiency, Fibra Danhos is better than Gicsa, as we may see in the following chart. It can be seen that GICSA has fewer NOI levels than Fibra Danhos, which shows the opportunities for improvements in the management and productivity of their shopping centers. Most of the buildings are valued at less than US\$20 per square meter. Only one asset, "Paseo Arcos Bosques," reaches more than US\$23 per square meter (which is, strangely, the only asset with shared participation with other companies). On the other hand, all the main centers of Fibra Danhos reach at least US\$20 per square meter, proving better efficiencies.
Therefore, the market entry proposition would be purchasing GICSA's malls' participation, in a majority position to take over control and operate. In this case, "Forum Buenavista" and "Paseo Interlomas," considering those two shopping centers are owned $100 \%$ by GICSA, which is not the case of "Paseo Arcos Bosques" on which they possess a 50\% of participation. The arguments of a selection of buying participation of Gica are summarized into the following points:

- "Forum Buenavista" and "Paseo Interlomas" are the Top-Tier Shopping Centers of Latin America and Mexico.

- The malls' age is relatively new (2008 and 2011, respectively), which means the cost of maintenance should not be very high compared to old ones. Moreover, the quality of the "Paseo Interlomas" building is remarkable.

- The tenant base is strong with some essential local retailers, such as Liverpool, El Palacio del Hierro, Sears, H\&M, and Zara.

- Entering those malls will allow high market renown and public visibility to Company X.

- There are opportunities for productivity and efficiency in NOI, compared with other companies such as Fibra Danhos.

- Buying the participation majority will allow them to control shopping centers and have GICSA as a local strategic partner.

- The location is strong in both cases, with a high flow of public traffic. Forum Buenavista is situated in the city center, next to the central station, where there are many public transport accesses. Paseo Interlomas is in a luxury district next to highways with easy access parking lots.

- The Cap rate of both Shopping Centers is among the industry average of Latin American Top-Tiers (7,5\%).

\section{Conclusion}

The Shopping Center industry has been increasing with a steady rhythm in Latin American countries, despite the tendency in other regions of the world such as the United States, where malls are disappearing. The trend in Latin America is due to different factors. However, the most important ones are middle-class incomes, which attained more financial security and access to credits, increasing over the last ten years, modifying the consumer basket of products and services to something above the basic ones, with more sophisticated preferences. Furthermore, the security that shopping centers grant to consumers is not available in most Latin American countries. Nevertheless, this increasing trend may be seen in several emerging market economies.

Four main objectives to understand the dynamics of shopping centers were indicated at the beginning of this paper:

- Recognize the key resources and capabilities to increase the likelihood to succeed in the Shopping Center sector in Latin America. 
- Recognize the most recommendable entry strategies in the Shopping Center sector in Latin America.

- Understand the economic, social, and political context of Mexico.

- Define an entry strategy to Mexico for the Shopping Center sector.

Thus, we recognized that resources such as iconic shopping center assets, human capital, reputation, high cash flow, portfolio of funds, landbanks portfolios, vertical integration, locations, and Infrastructure \& Designs are the most relevant to develop. Furthermore, elements such as human capacities, coordination activities, commercial mix, raising of financial funds, technology innovation capacities, customization, organization structure, and ability to transfer best practices are the essential capabilities to develop to be a thriving shopping center sector in Latin America.

Besides, the most recommendable entry strategies were recognized, and Mergers and Acquisitions (M\&A), Greenfield, and Joint Ventures (JV) are among there. Over which is also relevant to determine the recommendable capital obtention strategy to accomplish expansion goals, where we found bonds issuance, minority share sales, private investors, bank credits, own capital, and stock market openings.

By examining Mexico, we analyzed that it is an exciting market to invest in, being one of the most promising economies to 2050, with an increasing population level, forecasting a better population's acquisition power level in the future, which impacts tremendously in the shopping center sector. It is a well-developed real estate industry with real estate investment trusts (FIBRAS) and Development capital certificates (CKD), with a high market openness willing to receive foreign capital and one of the most ancient SC industry Latin America. Mexico is also among one of the best countries in the region and is positioned in various indices' top ranks. Nevertheless, corruption levels, bureaucracy, and security are topics to be aware of for international companies.

Thereby, the optimal entry strategy for company $\mathrm{X}$ to enter Mexico's shopping center industry would be an M\&A, buying majority participation for entering with a local partner who may contribute with capabilities and resources, oper- ate, and combine them with the ones that Company $\mathrm{X}$ has. The selected company to majority participation would be "GICSA," acquiring "Forum Buenavista” and "Paseo Interlomas" since they are Top-tier shopping centers in Mexico and Latin America. That strategy will allow the company to enter Mexico with a prominent market presence. It also has many other arguments, such as the infrastructure age and quality of the buildings, the excellent location, strong tenant base, reasonable Cap rate, and opportunities for efficiencies, as well as profitability in administration.

Following this thesis's theory, company $\mathrm{X}$ is involved only in emerging countries (Chile, Perú, and Colombia). These countries must deal with all the contexts that emerging economies represent (learning opportunities, political instability, level of security, etc.). The company may be considered "the international among others" regarding the interactive internationalization model, since other Chilean shopping centers and retail companies work in other Latin American sites, which is an excellent element to create a value chain. Besides, it was confirmed that many physical, human, and financial resources are vital for succeeding in Latin America's shopping center industry.

Regarding the main research questions: "Which are the key resources and capabilities to increase the likelihood to success in the Shopping Center sector in Latin America?" and "Which are the most recommendable entry strategies in the Shopping Center sector of Latin American countries?”, we can conclude that:

- Assumptions 2 and 3 ("experienced managers and teams" and "innovation-oriented policies") were confirmed.

- Many other answers were found in the study.

- In the second question, assumptions 1 and 2 were confirmed, but with significant emphasis on assumption 1 ("using a local partner").

Among limitations, it should be mentioned that it is necessary to further expand the analysis to other emerging countries. The shopping center sector is also an essential factor for such economies, such as Africa, Asia, or Eastern Europe. Besides, the study is based on a single case of company $\mathrm{X}$, limiting its generalizability. Therefore, additional research must be made to improve the results of the study questions. 
Humberto Riquelme, Vito Bobek, Tatjana Horvat: Shopping Center Industry Internationalization with a Focus on Key Resources and Direct Investment: The Case of a Chilean Company in Mexico

\section{References}

Asociación Española de Centros Comerciales. (2020). Retrieved from https://www.aedecc.com/centros-comerciales/

Asociación Mexicana de Capital Privado. (2014). Retrieved from: https://amexcap.com/contenido/resultados-de-la-encuesta2014-sobre-inversion-de-fondos-inmobiliarios-y-de-infraestructura-en-mexico

Bhat, A. (2020). Open-ended questions: definition, characteristics, examples, and advantages. Retrieved from https://www.questionpro. com/blog/what-are-open-ended-questions/.

Buckley, P. J., \& Ghauri, P. N. (1999). The internationalization of the firm. London: International Thomson Business Press.

Caprón, G. (1997). Urbanidad y modernización del comercio: Un análisis a partir del caso de los shopping centers en Buenos Aires. Buenos Aires: Universidad de Buenos Aires.

Cavusgil, T. S., Ghauri, P. N., \& Agarwal, M. R. (2002). Doing Business in Emerging Markets: Entry and Negotiation Strategies. Los Angeles: SAGE. https://doi.org/10.4135/9781483328720

Cepyme News. (March 2020). Las 3 estrategias competitivas genéricas de Michael Porter. Retrieved from https://cepymenews.es/ las-3-estrategias-competitivas-genericas-de-michael-porter.

Collis, J., \& Hussey, R. (2014). Business Research: A Practical Guide for Undergraduate and Postgraduate Students. Basingstoke, Hampshire, UK: Palgrave Macmillan.

Company X Portafolio. (2020). Retrieved from https://www.companyx.com/chile/

Company X. (2019). Memoria Anual, 2019. Santiago: Company X. Retrieved from https://www.america-retail.com/static//2020/07/ Memoria-Integrada-Company X2019.pdf

Dakar, O. Adebiyi, S. O., \& Amole, B. B. (2019). Exploring resources and capabilities factors among entrepreneurial ventures using DEMATEL approach. International Journal of Management, Economics and Social Sciences (IJMESS), 8(1), 20-39, https://doi. org/10.32327/IJMESS/8.1.2019.3

De Mattos, C. (2007). Globalización, negocios inmobiliarios y transformación urbana. Madrid: Nueva Sociedad.

Dirigentes Digital Magazine.(April 2020).10 aspectos a considerar antes de instalarse en un centro comercial. Retrieved from https:// dirigentesdigital.com/hemeroteca/10_aspectos_a_considerar_antes_de_instalarse_en_un_centro_comercial-EUDD13996

Ebster, C., \& Stalzer, L. (2008). Wissenschaftliches Arbeiten für Wirtschafts- und Sozialwissenschaftler. Vienna: Facultas.

ECLAC. (2011). India and Latin America and the Caribbean Opportunities and challenges in trade and investment relations. Santiago de Chile: Economic Commission for Latin America and the Caribbean.

ECLAC. (2016). Latin America's infrastructure investment situation and challenges. Santiago de Chile: Economic Commission for Latin America and the Caribbean.

Euromonitor. (2020). Mexico: It's all about the Middle Class. Retrieved from https://blog.euromonitor.com/mexico-its-all-aboutthe-middle-class/

Ferreira, J. M., \& Fernandes, C. I. (2017). Resources and capabilities' effects on firm performance: What are they? Journal of Knowledge Management, 21(4):00-00 https://doi.org/10.1108/JKM-03-2017-0099

Fisher, M. (2017). Qualitative Computing: Using Software for Qualitative Data Analysis. London, UK: Routledge.

Forbes. (14 ${ }^{\text {th }}$ March 2015). Retrieved from https://www.forbes.com.mx/mexico-el-pais-con-mas-centros-comerciales-en-al/

Gasca-Zamora,J.(2017). Centros comerciales de la Ciudad de México: el ascenso de los negocios inmobiliarios orientados al consumo. EURE. Revista latinoamericana de estudios urbano regionales., 75-84. https://doi.org/10.4067/s0250-71612017000300073

Gekonge, C. O. (2013). Emerging Business Opportunities in Africa: Market Entry, Competitive Strategy, and the Promotion of Foreign Direct Investments. Pennsylvania: IGI Global. https://doi.org/10.4018/978-1-4666-4570-7

Gottschalk, P. (2005). Strategic Knowledge Management Technology. Hershey, USA: Idea Group Inc (IGI). https://doi.org/10.4018/9781-59140-336-4

Hernández, J. S., \& Mirón, S. I. (2002). La teoría de los recursos y las capacidades. Un enfoque actual en la estrategia empresarial. Retrieved from https://s3.amazonaws.com/academia.edu.documents/54944382/Dialnet-LaTeoriaDeLosRecursosYLasCapacidades-793552.pdf?response-content-disposition=inline\%3B\%20filename\%3DLA_TEORiA_DE_LOS_RECURSOS_Y_LAS_CAPACIDA. ISSN 0213-7569.

International Council of Shopping Centers (ICSC). (2015). Reporte 2015 de la industria de centros comerciales en América Latina. Mexico DF: International Council of Shopping Centers (ICSC).

Johnson, G., Whittington, R., Regner, P., Scholes, K., \& Angwin, D. (2016). Exploring Strategy: Text and Cases. Edinburgh, UK: Pearson Education Limited.

KNOEMA. (2019). Mexico GDP Growth Forecast 2019-2024 and up to 2060. Retrieved from https://knoema.com/mpxyyob/mexicogdp-growth-forecast-2019-2024-and-up-to-2060-data-and-charts

KPMG. (2016). KMPG International Cooperative. Retrieved from Real Estate, un mercado de oportunidades en México: https://home. kpmg/content/dam/kpmg/mx/pdf/2016/10/Real-estate-esp\%20(SECURED).pdf

Lexology. (2020). Project finance in Mexico. Retrieved from https://www.lexology.com/library/detail.aspx?g=b06bd5f1-7bd6-47c8b520-5ea89e08ee8a 
Lipovestdky, G. (2014). La estetización del mundo. Barcelona: Editorial Anagrama.

Lizan. (September 2018). LRA Lizan Retail. Retrieved from http://lizanretail.com/the-shopping-center-industry-in-latin-america/

López-Cabarcos, M. Á., Göttling-Oliveira-Monteiro, S., \& Vázquez-Rodríguez, P. (2015). Organizational Capabilities and Profitability:

The Mediating Role of Business Strategy. SAGE Open. October 2015. https://doi.org/10.1177/2158244015616852

Luo, Y. (2002). Multinational Enterprises in Emerging Markets. Abingdon: Copenhagen Business School Press.

Martin Gonzalez, J. A. (2009). Claves del éxito de los centros comerciales. Madrid: Marketing MK.

Mayring, P. (2015). Qualitative Inhaltsanalyse: Grundlagen und Techniken (12. Auflage). Weinheim und Basel: Beltz Verlag.

Miles, B. M., \& Huberman, M. A. (1994). Qualitative Data Analysis: A Sourcebook of New Methods. New York: Sage Publications.

Olguín, C. (2019). Real Estate market \& lifestyle. Retrieved from https://www.realestatemarket.com.mx/articulos/capital-markets/11466-mexico-Lidera-centros-comerciales-en-america-latina-icsc

Porter, M. E. (2015). Ventaja competitiva: creación y sostenimiento de un desempeño superior. Mexico D.F.: Grupo Editorial Patria.

RB. (May 2017). Cómo se gestiona un centro comercial? la importancia della dashboard. Retrieved from https://www.rbasesoria-madrid.com/como-se-gestiona-un-centro-comercial-la-importancia-del-dashboard

Shopping Center Business. (March 2020). Shopping Center Business. Retrieved from https://shoppingcenterbusiness.com/?s=definition

Shumate, A., \& Watabaji, M. D. (2019). Effect of corruption and political instability on enterprises' innovativeness in Ethiopia: pooled data based. Journal of Innovation and Entrepreneurship, 8(1). https://doi.org/10.1186/s13731-019-0107-x

Tallman, S. (2010). Global Strategy. Chichester, UK: John Wiley \& Sons.

UNCTAD. (2020). World Investment Report 2020. Retrieved from https://unctad.org/system/files/official-document/wir2020_en.pdf, eISBN 978-92-1-005144-6.

WEF. (2015). The Global Competitiveness Index. Geneva: The World Economic Forum. ISBN-13: 978-92-95044-99-9.

WEF. (2016). The Global Competitiveness Index. Geneva: The World Economic Forum. ISBN-13: 978-1-944835-04-0.

WEF. (2017). The Global Competitiveness Index. Geneva: The World Economic Forum. ISBN-13: 978-1-944835-11-8.

WEF. (2018). The Global Competitiveness Index. Geneva: The World Economic Forum. ISBN-13: 978-92-95044-76-0.

WEF. (2019). The Global Competitiveness Index. Geneva: The World Economic Forum. ISBN-13: 978-2-940631-02-5.

\section{Internacionalizacija panoge nakupovalnih središč s poudarkom na ključnih virih in neposrednih naložbah: primer čilskega podjetja v Mehiki}

\section{Izvleček}

Zadnja leta panoga nakupovalnih središč beleži konstantno rast v Latinski Ameriki. Številne države, npr. Čile, Mehika in Brazilija, so vodilne $v$ tej regiji. Številni projekti so še $v$ fazi razvoja in portfelji različnih podjetij se spogledujejo z mednarodno širitvijo. Namen tega prispevka je določiti najbolj priporočljive vstopne strategije za države Latinske Amerike in osnovne vire ter zmogljivosti, ki jih potrebuje podjetje, ki ima v lasti nakupovalno središče, da bi povečalo svoje možnosti uspeha znotraj panoge. Zato smo analizirali različne dejavnike, ki vplivajo na delovanje te panoge, npr. politični, gospodarski in družbeni dejavniki, da bi pripravili splošen pregled najpomembnejših subjektov v tej panogi. $\vee$ ta namen smo uporabili primarne in sekundarne podatke, pridobljene s pomočjo pregleda literature in empirične kvalitativne študije, pridobili informacije o čilskem nepremičninskem podjetju in intervjuvali vodilne menedžerje. S pomočjo rezultatov smo pripravili predlog strategije vstopa na mehiški trg in določili najpomembnejša nakupovalna središča v državi, glavne akterje in najboljše možnosti za vstop.

Ključne besede: nakupovalno središče, viri in zmogljivosti, vstopne strategije, nastajajoči trgi, Čile, Mehika 